\title{
The Determinants of Sin Stock Returns: Evidence on the European Market
}

\author{
Julie Salaber: Paris-Dauphine University, Paris Cedex 16, France
}

CONTACT: Julie Salaber, Paris-Dauphine University, Place du Marechal de Lattre de Tassigny, 75775 Paris Cedex 16, France.

Email: Julie.Salaber@dauphine.fr

November 2007

This article deals with the time-series variation in average sin stock returns - returns on publicly-traded companies involved in producing tobacco, alcohol, and gaming. Next to nothing has been written about this class of stocks, especially on the European stock market. The hypothesis I explore in this paper is that sin stock returns depend on legal and cultural characteristics such as religious preferences, the level of excise taxation, and the degree of litigation risk. Using data on 18 European countries over the period 1975-2006, my results show evidence that Protestants are more "sin averse" than Catholics, and require a significant premium on sin stocks. Moreover, sin stocks have higher risk-adjusted returns when they are located in a country with high excise taxation; and sin stocks outperform other stocks when the litigation risk is higher, even after controlling for well-known risk factors such as market capitalization and book-to-market ratio. These findings suggest that sin stock returns depend on both legal and religious environments of each country.

Keywords: European markets, sin stocks, religion, taxation, litigation.

JEL Classifications: G12, G14, G15.

I would like to thank seminar participants at Georgia State University and the 2007 AFFI conference for their valuable comments and suggestions. 


\section{The Determinants of Sin Stock Returns: Evidence on the European Market}

\section{Introduction}

Stocks of companies involved in producing tobacco, alcohol and gaming are usually called sin stocks. These stocks are of increased interest since more and more investors and fund managers avoid them while integrating social screening with their investment decisions. Socially responsible investment (SRI) combines investors' financial objectives with their concerns about social, environmental and ethical issues. Socially responsible investing and avoiding investment in sin stocks are not always the same, but sin stocks are the most often negatively screened stocks by socially responsible investors. Hong and Kacperczyk (2007) study the performance of sin stocks on the American market. They find that sin stocks outperform the market due to the fact that they are less held by institutions subject to social norms, over the period 1965-2003. While gauging the relative importance of litigation risk versus this neglect effect, the authors find that litigation risk cannot explain the abnormal returns on sin stocks. Kim and Venkatachalam (2006) examine whether this neglect effect is attributable to differential information risk for these firms; i.e. sin stocks may possess greater information risk due to poor financial reporting quality. They show that sin firms' financial reporting quality is superior to a control group of firms, implying that the neglect by market participants is not attributable to financial reporting factors. It seems that, despite superior returns and higher financial reporting quality, investors are willing to pay a financial cost in order to comply with societal norms. The conclusion emerging from these US studies is that some investors reflect non financial tastes in their portfolio by neglecting sin stocks.

In this paper, I use a sample of 18 European countries with different legal and cultural environments in order to examine the determinants of sin stock expected returns. These countries are Austria, Belgium, the Czech Republic, Denmark, Finland, France, Germany, Greece, Hungary, 
Ireland, Italy, the Netherlands, Poland, Portugal, Spain, Sweden, Switzerland, and the UnitedKingdom. Alcohol, tobacco and gambling stocks are the most often negatively screened stocks by socially responsible investors and funds, with a fourth industry: defense ${ }^{1}$. On the other hand, sin stocks are positively screened by some "politically incorrect investment" promoters. The American Vice Fund invests in those four sectors (alcoholic beverages, tobacco, gaming and defense). Moreover, two recent books on sin investment [Waxler (2004) and Ahrens (2004)] concentrate on the same four sectors. However, the defense industry is not as homogeneous as the three other sectors. Firstly, the defense industry across Europe includes very different companies with a broad diversity in their activities. Secondly, alcohol and tobacco consumption, as well as gambling, are considered sinful behaviours for some religious denominations, the most prevalent example being Islam; whereas defense does not have this sinful quality. Thirdly, gambling, drinking and smoking constitute three types of addictive behaviour, implying high external costs in terms of healthcare; and all three products have limited substitutes. Finally, tobacco, alcohol and gambling are subject to excise taxes which are discriminating by definition and are levied to reflect the external costs, as well as to discourage consumption. For all the above reasons, I exclude the defense industry from my analysis. Other industries could be considered sinful, such as the sex industry, but are hardly represented on the European stock markets. Moreover, excluding defense and sex stocks in my sin portfolio is more relevant for the purpose of this study, and should not affect the analysis ${ }^{2}$.

US studies on sin stocks find that some investors avoid this type of investing, despite higher risk-adjusted returns, and explain this result by negligence due to social norms. I investigate other possible explanations with regard to the behaviour of investors toward alcohol, tobacco and gambling products, as well as the impact of the government's intervention on financial markets. I study the behaviour of sin stocks in 18 European countries with different legal and cultural characteristics, such as legislation, taxation, consumption, and religion, in order to find the determinants of their riskadjusted returns. Religion and legislation have been widely related to economic growth and economic

\footnotetext{
${ }^{1}$ For instance, the Dow Jones Sustainability Index STOXXSM Ex All excludes alcohol, gambling, defense and tobacco industries.

${ }^{2}$ Hong and Kacperczyk (2007) report results excluding the defense industry, but say that their results remain qualitatively similar when defense stocks are included in the analysis.
} 
attitudes [Guiso, Sapienza, and Zingales (2003), McCleary and Barro (2006), and Jacob and Osang (2006) for instance], but researchers have paid little attention to religion and legislation as determinants of stock prices.

The analysis of sin stocks on a European scale is very interesting for many reasons. First, as a whole, Europeans have the highest alcohol consumption rate ${ }^{3}$, are the biggest producers of alcohol ${ }^{4}$, and have the highest excise taxation of the world. Moreover, all European countries in this study have a majority of Christian populations, with two main denominations, Catholic and Protestant (only Greece is primarily Orthodox). Second, at a state level, all countries have differences in their cultural and legal environments, such as consumption rate, taxation system, religious beliefs, government regulation, and litigation risk. The common basis makes it possible to study markets which are homogeneous compared to the rest of the world, and the different environments can help explain differences in stock returns. I assume in this paper that European markets are segmented. Agents consume and invest in their own country and expected stock returns can be different across countries, due to the fact that risk premiums depend primarily on country-specific factors. This assumption is somewhat realistic and is useful in order to investigate the impact of national environments on expected stock returns.

My paper proceeds as follows. In the next Section, I present previous literature on religion, legislation, and taxation and I develop the hypotheses I want to test. In Section III, I present all the data, as well as my methodology for portfolio formation. Section IV presents the empirical results for both one-factor and three-factor models. Section V concludes and offers some perspective for future research.

\footnotetext{
${ }^{3}$ Adults in the European Union drink on average almost 13 litres of pure alcohol per year, two-and-a-half times the average for the rest of the world. The consumption per drinker reaches 15 litres per year if abstainers are excluded. This is equivalent to 600 bottles of beer $(50 \mathrm{cl}, 5 \%), 167$ bottles of wine $(75 \mathrm{cl}, 12 \%)$ or 54 bottles of spirits (70cl, 40\%). (Source: 2004 WHO Global Status Report on Alcohol)

${ }^{4}$ France, Italy and Spain together produce half of the world's wine and Germany $7.5 \%$ of the world's beer, while the UK is the world's leading producer of whisky and gin, and Poland of vodka. (Source: 2004 WHO Global Status Report on Alcohol)
} 


\section{Related literature and hypotheses}

\section{Why should religion matter in economy and finance?}

The relationship between religion and economic growth has been widely studied in the literature. McCleary and Barro (2006) show that the economic development of a country is associated with less religiosity, in the way that church attendance affects religious beliefs, which affect individual traits, which affect economic performance. For given religious beliefs, they find that an increase in church attendance implies a decrease in economic growth; whereas, for given church attendance, higher religious beliefs imply higher economic growth. These opposite results have been criticized by Guiso, Sapienza, and Zingales (2003) who invoke the existence of country-fixed effects. These authors examine the impact of religion on different economic attitudes over 66 countries. They find that religious people trust the government more, are less willing to break the law, and believe more in the fairness of the market; but they are more intolerant. In addition, their estimates are very similar for both Protestants and Catholics. Jacob and Osang (2006) find a non-linear relationship between religiosity index (accounting for religious attitude, beliefs, practice and preference) and economic development, measured by per capita income.

Religion should also matter for finance, and evidence can be found in corporate literature. Hilary and Hui (2006) examine the influence of community religion on corporate decisions in the US. They start with the positive relationship that exists (and has been suggested by prior research in psychology and anthropology) between individual religiosity and risk aversion. As a consequence, they observe that firms with religious tendencies, or residing in a religious environment, have lower risk exposure measured by the variance in equity returns and in ROA - and require a higher internal rate of return (ROA). They also compare Protestant and Catholic denominations and find that both have a significant effect on risk and return. Stulz and Williamson (2003) examine the impact of religion and legal origin on investor protection in 49 countries. They categorize countries according to their primary religion (Protestant vs. Catholic) or their legal origin (common law vs. civil law), and study investor protection according to three notions: creditor rights, shareholder rights, and the rule of law. The relationship is higher between religion and both creditor rights and the rule of law, whereas 
shareholder rights are more correlated with a country's legal origin. Creditor rights are stronger in countries where the main religion is Protestant rather than Catholic, regardless of legal origin. The enforcement - measured by the efficiency of the judicial system, the rule of law, and a corruption index - is significantly stronger for Protestant than for Catholic countries. The correlation between religion and shareholder rights is not obvious, since the estimation shows that Protestant countries make it easier for shareholders to vote and sue, but harder to make their vote count when they vote.

If I predict that religion could have an impact on financial markets, I have to investigate why this impact would be specific to sin stocks.

\section{Sin regulation and religious denomination: Catholic vs. Protestant}

Many factors affect an individual's attitudes toward the legal vices of smoking, drinking, and gambling, but religion is probably the most important. Smoking, drinking and gambling are considered major sins by the Islamic ruling, and stays a taboo in Muslim populations. In Christian denominations, alcohol and tobacco are not considered as religious sins, except for Fundamentalists. But it seems that smoking, drinking and gambling are considered in a very different way between Catholic and Protestant populations. In the US, where the main denominations across states are Catholic and Protestant, researchers find a strong relationship between religious preference and sin regulation. Fairbanks (1977) examines the correlation between church groups and restrictiveness of liquor and gambling laws, and finds that Protestants support strict liquor and gambling controls, whereas Catholics are hostile to liquor and gambling prohibition. On one hand, both conservative and liberal Protestant denominations frequently oppose legalized gambling; the conservatives on spiritual grounds, and the liberals on social-welfare grounds. On the other hand, betting games such as bingo have a long tradition in the Catholic Church, and drinking in moderation has been accepted. Johnson and Meier (1990) find that states with a large Catholic population are more likely to legalize gambling than Protestant states. It seems that religion matters for investors' attitude toward sin, and the question of sin regulation raises another issue: the taxation of alcohol, tobacco, and gambling products. 


\section{Excise taxation of sin products}

Excise taxation comprises all selective taxes and related levies and charges on tobacco, alcohol, gambling, pollution, driving, and other specific goods, services and activities [Cnossen (2005)]. Excise taxation is selective in coverage, and discriminating in intent. The main objectives of excise taxation are to raise revenue for general purposes, to reflect external costs, and to discourage consumption. For revenue purposes, the higher taxation of addictive products such as tobacco, alcohol, and gambling has an economic rationale, which is the absence of close substitutes implying demand inelasticity. This rule, known as the Ramsey (1927) rule, states that, in order to minimize total excess burden, tax rates should be set so that the percentage reduction in the quantity demanded of each commodity is the same. A direct consequence of this rule is the inverse elasticity rule, which says that as long as goods are unrelated in consumption, tax rates should be inversely proportional to elasticity. Corlett and Hague (1953) explain that excise systems are also an indirect means of leisure taxation, allowing for a better resource allocation. The second objective of excise taxes is to reflect the charges for external costs (physical, financial, and psychological costs) that consumers or producers of excisable products impose on others. The third objective of excise taxation is to restrain the consumption of products regarded as unhealthy. Excise taxes also provide external incentives for desirable conduct; that is, they induce extrinsic motivation. European excise taxes on alcoholic beverages and tobacco are the highest in the world. Taxation and pricing is the preferred overall measure to reduce the external costs of both harmful drinking [Babor et al. (2003)] and smoking [Van Liemt (2002)]. The issue of excise taxation is whether the costs of these selective taxes on alcohol, tobacco, and gambling have an impact on sin stock returns.

\section{Litigation risk for sin companies}

Because of the nature of their business, sin firms face higher litigation exposure in their product markets than non-sin firms. Litigation means that the industry cannot do without the assistance of a sizeable number of legal experts. This cost factor is particularly high for the tobacco industry. Tobacco firms face three types of litigation, which are individual personal injury, class action personal injury, and health care cost recovery. This litigation risk is also applicable to other sin industries since they 
have to face a social cost for sin consumption (social cost is the sum of private cost and external cost). If the health care cost is obvious for tobacco and alcohol consumption, the damages are also very important for gambling. International literature on health shows that gambling has far reaching negative effects on the health, wellbeing and quality of life of individuals, families and communities. The Problem Gambling Foundation of New Zealand ${ }^{5}$ defines two types of unhealthy gambling. "Problem gambling" refers to gambling that significantly interferes with a person's basic occupational, interpersonal, and financial functioning. "Pathological gambling" is the most severe form and is classified as a mental disorder with similarities to drug abuse. People with problem gambling may experience stress-related physical and psychological ill health.

The costs of the many lawsuits and the risk that important damages may need to be paid require management attention and have depressing effect on the prices of sin stocks. These companies have comparatively low price/earnings and low price/book ratios. Litigation risk also gives the industry a poor image, a serious matter for companies which rely so much on the "feel good" factor in the marketing of their products.

\section{Testable hypotheses}

The first hypothesis concerns the relationship between religious denominations and sin stock returns. Stulz and Williamson (2003) find that investor protection, especially through creditor rights and the rule of law, is stronger in countries where the main religion is Protestant rather than Catholic. Moreover, Fairbanks (1977) and Johnson and Meier (1990) find that Protestants support strict alcohol and gambling controls, whereas Catholics are hostile to liquor and gambling prohibition. Knowing that Protestants are less willing to promote sin, and that investors require more investment protection in a Protestant environment, I can predict that investors residing in Protestant countries will exhibit what I call "sin aversion" when investing on financial markets. In other words, investing in sin stocks is against their risk preferences. They should require higher expected returns on sin stocks compared to other stocks. Investors in Catholic countries should not exhibit this "sin aversion" since alcohol, tobacco, and gambling are not considered sinful by the religious denomination. Thus, the first

\footnotetext{
${ }^{5}$ www.problem-gambling.info
} 
hypothesis I test is whether there is a risk premium on sin stocks in countries where the major religious denomination is Protestant.

H1: Sin stocks exhibit higher risk-adjusted returns than other stocks, only in Protestant countries.

The second hypothesis treats the litigation risk as a determinant of expected returns on sin stocks. Smoking, drinking, and gambling are addictive attitudes which imply personal and external costs. Alcohol and tobacco consumption are unhealthy, and gambling is now recognized as dangerous for health. Thus, companies in these three industries have a high litigation exposure through the need of legal experts, the cost of many lawsuits, and the possibility of costs recovery. This litigation risk might have a depressing effect on stock prices and require higher expected returns on sin stocks than on other stocks. I test here whether a higher litigation risk implies higher risk-adjusted returns on sin stocks, but not on other stocks.

H2: Sin stocks have higher risk-adjusted returns than other stocks in countries with high litigation risk.

The third hypothesis I want to test deals with the relationship between excise taxation of sinful products and stock returns on firms producing these products. One of the objectives of excise taxes is to reflect the external costs related to the unhealthy nature of the excisable products. Smoking, drinking, and even gambling are well-know addictive behaviours, and both consumers and producers have to pay the external cost they impose on others. Thus, excise taxes should be high enough to cover these external costs. Another argument for high excise taxes is the inverse elasticity rule based on the inelasticity of demand for tobacco, alcohol, and gambling. Indeed, these products are relatively insensitive to price, especially because of limited number of substitutes for consumers. Therefore, it is commonly accepted that excise taxes should be high and, in fact, excise taxation in Europe is on average very high compared to other developed countries. However, excise duties differ widely between European countries. For instance, alcoholic beverages are heavily taxed in Sweden, Ireland, the UK and Finland, but are less taxed in Austria, the Czech Republic, Hungary, and the 
Mediterranean countries ${ }^{6}$. One can imagine that these differences in excise taxes would have an impact on stock prices, and therefore on stock returns. Only sin stocks should be concerned, since excise taxation is selective and discriminating by definition. As for litigation risk, firms exposed to higher excise taxes will have comparatively lower price/earnings and price/book ratios. The cost represented by higher excise duties may depress stock prices for companies producing these excisable products. If sinful products are heavily taxed, my prediction is that sin stocks should need higher expected returns than other stocks to integrate this constraint. The last hypothesis I test is whether higher excise taxation implies higher risk-adjusted returns on sin stocks, but not on other stocks.

H3: Sin stocks with high excise taxation have higher risk-adjusted returns than both other stocks and sin stocks with low excise taxes.

I argue that the performance of sin stocks depends on both the level of excise taxation and the degree of litigation risk, as well as the religious denomination of each country. After presenting my sample data, and collecting several measures of religion, taxation, and legislation, I test whether different national environments can help explain the cross-sectional variation in expected returns on sin stocks, after adjusting for well-known risk factors such as market, size, and book-to-market.

\section{The Data}

\section{Financial data}

This study focuses on sin stocks for 18 European countries over the period 1975-2006. Every stock in the sample belongs to one of the following countries: Austria, Belgium, the Czech Republic, Denmark, Finland, France, Germany, Greece, Hungary, Ireland, Italy, the Netherlands, Poland, Portugal, Spain, Sweden, Switzerland, and the United-Kingdom. Two European countries have been removed from the sample (Luxembourg and Norway) because there is no publicly-traded sin company for these countries. The sample consists of all common stocks available in Thomson DataStream. Moreover, I add to the sample all firms that disappear. Dead stocks are defined as stocks that merged, defaulted or were delisted. Thus, the data is relatively free of survivorship bias. Moreover, I use the

\footnotetext{
${ }^{6}$ Source: Cnossen (2006)
} 
methodology of Ince and Porter (2006) in order to screen Thomson DataStream data and keep only relevant stocks ${ }^{7}$.

I remove from the sample all financial companies for which the ratios do not have the same significance and are constrained by strict regulation. In addition, some stocks do not have as many price-to-book observations as return observations over the analysis period, excluding the fact that price-to-book data is only available from 1980. Other stocks have no available data on their industrial sector or the return index. These stocks are also discarded from the sample. After cleaning the dataset, I have a total number of 6,350 stocks across 18 countries, over 384 months. Table 1 summarizes the data. For each country, it indicates the number of stocks in the sample, the average size and the median size in 1985, 1995 and 2005. The last part of the Table shows the average price-to-book ratio per country in 1985, 1995 and 2005. The United-Kingdom is the biggest European market in terms of number of firms, followed by Germany and France. In the early years of the sample, not all stocks are already listed, pushing downwards the number of stocks in the analysis. In December 1985, there are 747 stocks in the sample, while this number reaches 4,717 in December 2005. In December 2005, Denmark and UK have the highest price-to-book ratios (more than 5 on average), whereas Hungary has the lowest in average (close to one). These differences in price-to-book ratios across countries are not very large, and could be explained by some heterogeneity in the accounting methods.

In order to mitigate any currency effects, I choose to work with euro rate of returns. Stock prices are available at the end of each month, but information about dividends is limited to the dividend yield, only allowing calculation of annual returns. Since I need to calculate monthly returns, I retrieve an index created by DataStream which takes into account the dividends payment. The return index for any equity shows its theoretical growth in value, assuming that dividends are reinvested to purchase additional units of this equity at the closing price applicable on the ex-dividend date ${ }^{8}$. I retrieve the return index, the market capitalization, the ratio price-to-book value and the exchange rates from DataStream from December 1974 (December 1980 for price-to-book data) to December 2006. The

\footnotetext{
${ }^{7}$ For instance, I screen the variables TYPE, NAME, and GEOG to identify and delete non common stocks and nonlocal firms.

${ }^{8}$ Gross dividends are used where available and the calculation ignores tax and re-investment charges. Adjusted closing prices are used throughout to determine price index and hence return index.
} 
price-to-book ratio for month $t$ is defined as the share price at the end of month $t$ divided by the current book value per share (ratio book value to total shares outstanding) ${ }^{9}$. Since the analysis is done on a European scale, I use only one interest rate to measure the risk-free rate in Europe. From $1^{\text {st }}$ January 1999, one can use the one-month Euro interest rate. But before this date, I have to assume that there is no exchange risk and choose one of the euro-zone interest rate. I test the robustness of my results to several European interest rates and the conclusions remain unchanged. All the estimation results presented in this paper use portfolio returns in excess of the one-month German interest rate.

I select sin stocks according to the DataStream classification into 'brewers', 'distillers and vintners', 'gambling', and 'tobacco'. The list of all sin stocks present in the database is available from the author. Over the entire period, there are 158 sin stocks, distributed as follows: 49 stocks belong to the brewers sector, with well-known companies such as Heineken or Inbev - owning the brands Stella Artois, Leffe and Hoegaarden; 47 stocks are classified in distillers and vintners, with for instance Campari, Taittinger, Pernod-Ricard or Grand Marnier; the gambling industry accounts 51 stocks like Groupe Partouche (casinos in Belgium and France) and Betandwin.com (betting on Internet); and 11 stocks belong to the tobacco sector as for example Altadis or BAT. These low numbers are due to the fact that many sin companies are privately held. All those 158 stocks are not present at the same time in the study. Table 2 indicates the evolution of this sub-sample for each year between 1980 and 2006, compared to the evolution of other stocks. One can see that, before 1988, the number of sin stocks is lower than 30, and increases to 123 in December 2005. The average firm size and the median firm size are higher for sin stocks than for non-sin stocks. This is due to the fact that my sample includes all stocks listed, and that the large number of small capitalizations lowers the average size on the market. The average price-to-book value of sin stocks is lower than the price-to-book ratio of other stocks over the entire period, except for 1998, 2000 and the last 5 years; which means that sin stocks can be considered as value stocks compared to other stocks. This relatively low price-to-book ratio for sin stocks is consistent with Hong and Kacperczyk (2007), as well as with the idea that litigation risk has a depressing effect on prices.

\footnotetext{
${ }^{9}$ The current book value is the latest book value shown on the balance sheet. Total shares outstanding are as of latest balance sheet date adjusted for capital changes.
} 
Once I have my list of sin stocks, I calculate the excess monthly return net of the risk-free rate for two value-weighted portfolios, including respectively my sin stocks and all other stocks. Because I focus on the performance differential between sin stocks and other stocks, I also provide the riskadjusted returns on a zero-investment portfolio, long on sin stocks and short on other stocks ${ }^{10}$.

To test my predictions, I use a European version of the well-known three-factor model from Fama and French (1993). In order to calculate the market, SMB and HML portfolio returns, I can form either country portfolios or global portfolios. According to Fama and French (1998), portfolios restricted to individual countries are less diversified and their returns have large idiosyncratic components [e.g., Harvey (1991)]. As a result, asset pricing tests on country portfolios are noisier than tests on global portfolios. Moreover, Fama and French (1998) use a two-factor model that explains returns with a global market return and a risk factor for relative distress (high minus low book-tomarket portfolio), and find that this two-factor model captures the value premium in both country and global returns. In any case, the sin stock sample size used in this analysis is too small to construct meaningful country portfolios. For instance, several sin portfolios for particular countries during certain months would contain as little as two stocks, whereas the non-sin portfolios for the same months would include all other stocks ${ }^{11}$. Thus, I calculate the value-weighted return on global factors which are a market portfolio, a SMB portfolio, and a HML portfolio. For the market portfolio, I use all stocks for which data on return and market value are available for at least twelve months. For SMB and HML portfolios, I follow Fama and French (1993) using all stocks for which I have data on market value at the end of June $t$ and price-to-book ratio at the end of December $t-1$. I then construct six portfolios BL, BH, BM, SL, SH, and SM where stocks are ranked into two size groups (50-50) and three book-to-market groups (30-40-30). SMB is the difference between the small-cap portfolios average return (SL, SH, SM) and the large-cap portfolios average return (BL, BH, BM). HML is the difference between the value portfolios $(\mathrm{BH}, \mathrm{SH})$ average return and the growth portfolios (BL, SL) average return.

\footnotetext{
${ }^{10}$ I also compute equally-weighted returns for my sin, non-sin, and long-short portfolios, but I do not find this estimation procedure very relevant.

${ }^{11}$ This was the case for Ireland, Denmark, Switzerland, Hungary, Portugal, Finland, and the Czech Republic, which only contained one or two sin stocks in December 2005.
} 


\section{Religion data}

I first use several sources to classify countries between different religious denominations. Following Stulz and Williamson (2003), I define the primary religion as the one practiced by the largest fraction of the population of a country. The data on religion come from the 2000 CIA World Factbook, and give the dominant religions in each country with the proportion of the population affiliated to each major religion. Table 3 shows the primary religion for each country, as well as the distribution of all major denominations per country. Many other sources on religious statistics validate these figures ${ }^{12}$. All European countries in the sample are Christian, distributed between Catholic denomination - Austria, Belgium, the Czech Republic, France, Hungary, Ireland, Italy, the Netherlands, Poland, Portugal, Spain, and Switzerland - and Protestant denomination - Denmark, Finland, Germany, Sweden, and the UK -, while only Greece has a primary Orthodox religion ${ }^{13}$.

Some studies on the economics of religion distinguish between religious beliefs and religious practice. Religious beliefs are dependent on religious teachings, and how those teachings are interpreted by adherents. For instance, religious beliefs can be measured by the belief in God, or heaven, or hell. Religious practice measures the intensity of beliefs and can be proxied by the frequency with which individuals attend religious services. Religious beliefs and church attendance can be both related to religious denomination (Catholic vs. Protestant). Iannaccone (1998) and McCleary and Barro (2006) find that church attendance is higher for Catholic countries than for Protestant countries. McCleary and Barro (2006) also find that Protestants have lower religious beliefs. I thus use data on church attendance and religious beliefs to check the robustness of my religious measures. Weekly or monthly church attendance measures the proportion of adults attending religious services, at least weekly or monthly, apart from weddings, funerals and christenings. The other measure concerns religious beliefs and attitudes; for example, do you believe in heaven, hell, and God? Other questions are whether the individual considers himself or herself to be a religious person and whether religion plays an important role in a person's life. I use McCleary and Barro (2006),

\footnotetext{
${ }^{12}$ See www.adherents.com, www.religionstatistics.net, www.thearda.com, and www.worldchristiandatabase.org.

${ }^{13}$ In Germany, the Netherlands, and Switzerland, the fraction of the population practicing the Catholic religion is close to the fraction practicing a Protestant religion. I then follow Stulz and Williamson (2003) to classify these countries.
} 
Guiso, Sapienza, and Zingales (2003), and the World Value Survey 1999 (a cross-country project coordinated by the Institute for Social Research of the University of Michigan) to categorize my sample countries into two groups based on church attendance and two groups based on religious beliefs $^{14}$. Panel A of Table 4 shows that all Protestant countries have low church attendance, consistent with Iannaccone (1998) and McCleary and Barro (2006). Panel B shows that countries with low church attendance usually have low religious beliefs - for example the Czech Republic, Denmark, France, Hungary, and Sweden -, while countries with high religious beliefs generally have also high church attendance, such as Ireland, Italy, Poland, and Spain. But church attendance and religious believes are not correlated for all countries. Finland (Protestant) and Greece (Orthodox) have low church attendance but high religious beliefs; whereas two Catholic countries - Belgium and the Netherlands - have low religious beliefs and high church attendance.

All these measures are consistent with previous literature, since Protestants have lower church attendance and lower religious beliefs than Catholic. I choose the country classification between Catholic and Protestant to test my first hypothesis.

\section{Taxation and legislation data}

Stulz and Williamson (2003) show that the stock market development is correlated with a country's legal origin (common law vs. civil law). The 2000 CIA World Factbook provides the legal system for each country. Unfortunately, out of 18 countries, only two have common law tradition (Ireland and the UK). Therefore, I cannot compare between different legal origins because of the large asymmetry.

The litigation risk in a country can be defined as the risk, for a company located in this country, of being subject to lawsuits. It also includes present and future litigation costs such as health care cost recovery. This risk is relatively higher for sin firms than for others, but depends also on the legal environment of the firm, such as the enforcement of the law, or the probability of being sued. I proxy the tradition for law with a measure called rule of law. La Porta, Lopez-de-Silanes, Shleifer and Vishny (1997) define the rule of law as the assessment of the law and order tradition in a country. My

\footnotetext{
${ }^{14}$ I also validate my classification using statistics from www.adherents.com and www.religionstatistics.net.
} 
data come from the World Bank and are presented in Table 5. The country with the highest tradition for law is Denmark, whereas Poland has the lowest rule of law. I form two groups of countries based on this measure of enforcement. However, Stulz and Williamson (2003) show that enforcement measured by the efficiency of the judicial system and the rule of law - is significantly stronger for Protestant than for Catholic countries. In fact, all Protestant countries are in the same group of higher rule of law. The two classifications are not redundant, since I also have Catholic countries with a high tradition for law, but I am not able to distinguish between the two effects: religion and enforcement.

I use two other measures for the level of litigation risk in a country. The first one is the number of lawyers per capita in a given country. The second one is an estimated litigation rate per country, measured by the number of judicial cases per inhabitant in a year. Both measures give an estimation of the probability, for a company, to be sued. Data on lawyers is from the $2006 \mathrm{CEPEJ}^{15}$ Report on European judicial systems and give, for 2004, the total number of lawyers per 100,000 inhabitants. Data on litigation rate is from Wollschlager (1998) and covers 14 European countries over the year 1990. These two measures are also given in Table 5. In addition, Figure 1 plots the number of lawyers vs. the litigation rate - for countries for which both data are available -, and shows that the two sorting are not redundant. I then can test my predictions on litigation risk with these tow different measures.

I finally want to test whether excise taxation has an impact on sin stock returns. I use data from Cnossen (2005) for the excise tax on tobacco, and from Cnossen (2006) for excise taxation on alcoholic beverages. A summary of excise duty rates for each country is given in Table 6 , in increasing order of beer taxation. The excise tax on tobacco has two components, a specific excise and an ad valorem excise; the tax is given in euro, per pack of 20 cigarettes, and figures are for 2003 . The excise duty rates on alcoholic drinks are also given in euro, and data is for 2006. Beer excise tax is based on $5 \%$ abv (alcohol by volume), wine excise duty is based on $12 \%$ abv, and spirits tax is given for $40 \%$ abv. All excise taxes are highly correlated, in the sense that the same countries have high (respectively low) taxation on beer, wine, spirits, and tobacco (see for instance Figure 2 which plots tobacco excise tax vs. beer excise duty). I keep the excise duty on beer as a measure of taxation, since more data is available for alcohol excise taxes, and beer is the most popular alcoholic drink. When I compare

\footnotetext{
${ }^{15}$ European Commission for the Efficiency of Justice
} 
Protestant countries with countries with higher beer excise taxation, I find that 4 out of 5 Protestant countries have high excise taxes ${ }^{16}$, which is consistent with Johnson and Meier (1990) who show that countries with more Protestants should be more likely to have higher taxes on alcohol and tobacco. They argue that attitudes toward the use of alcohol and tobacco as well as toward gambling are of major concern to some churches. In the US, political action by Protestant fundamentalists, particularly in regard to gambling and alcohol, has always been high [Hutcheson and Taylor (1973)]. And Catholics stand in opposition to Protestants on these issues [Fairbanks (1977)]. Countries with a large Catholic population should therefore have lower sin taxes and be more likely to support gambling. Here my measure of excise duties allows little interpretation about the relative impact of religion and taxation on stock returns ${ }^{17}$. However, my prediction about religion concerns the difference in riskadjusted returns between sin stocks and non-sin stocks, only in Protestant countries; whereas the hypothesis on excise taxation deals with the difference in risk-adjusted returns on sin stocks between highly taxed and lowly taxed countries.

\section{Empirical results}

I first estimate the Capital Asset Pricing Model (CAPM) of Sharpe (1964) and Lintner (1965). The abnormal return on any portfolio is given by the intercept of the CAPM model of the form

$$
\mathrm{EXR}_{\mathrm{p}, \mathrm{t}}=\alpha_{\mathrm{p}}+\beta_{\mathrm{p}} \mathrm{EXR}_{\mathrm{m}, \mathrm{t}}+\varepsilon_{\mathrm{p}, \mathrm{t}}
$$

where $\mathrm{EXR}_{\mathrm{p}}$ is the return of the portfolio in excess of the one-month German interest rate and $\mathrm{EXR}_{\mathrm{m}}$ represents the excess return on the value-weighted market portfolio. I also test my predictions using the three-factor model of Fama and French (1993), which explains the excess returns on any portfolio $\mathrm{EXR}_{\mathrm{p}}$ by the equation

$$
\mathrm{EXR}_{\mathrm{p}, \mathrm{t}}=\alpha_{\mathrm{p}}+\mathrm{b}_{\mathrm{p}} \mathrm{EXR}_{\mathrm{m}, \mathrm{t}}+\mathrm{s}_{\mathrm{p}} \mathrm{SMB}_{\mathrm{t}}+\mathrm{h}_{\mathrm{p}} \mathrm{HML}_{\mathrm{t}}+\varepsilon_{\mathrm{p}, \mathrm{t}}
$$

where $\mathrm{SMB}_{\mathrm{t}}$ is the Small Minus Big capitalization portfolio in month $\mathrm{t}$ and $\mathrm{HML}_{\mathrm{t}}$ is the High Minus Low book-to-market portfolio in month t. These two models will allow me to compare the returns on sin stocks and other stocks across different groups of countries. Before testing my different

\footnotetext{
${ }^{16}$ The only Protestant country with low beer excise tax is Germany, a well-known beer drinker country.

${ }^{17}$ If I group my countries on tobacco excise tax, all Protestant countries are in the same taxation group.
} 
hypotheses, I estimate the two models for the sin, non-sin and long-short portfolios, for the entire sample of countries. The empirical result in Table 7 shows that sin stocks outperform on average other stocks, even after accounting for size and book-to-market factors, which is consistent with the conclusions of Hong and Kacperczyk (2007). The zero-investment portfolio, long on sin stocks and short on non-sin stocks, has a positive alpha of 5.4\% annually, which is significant at a ten percent level. If I look at the sensitivity of my portfolios, the non-sin portfolio has a beta almost equal to one, which is not surprising since it includes nearly all stocks, except sin stocks. However, the sin portfolio has a beta lower than unity, implying that sin stocks are not very sensitive to market variations. The beta of the long-short portfolio is significantly negative, meaning that the zero-investment portfolio is not a zero-beta portfolio; it has a negative exposure to the market. Another interesting feature is that my sin portfolio is heavily loaded on the HML factor, the coefficient being statistically significant at a one percent level. This high value premium is consistent with the relatively low price-to-book ratio for sin stocks compared to other stocks. All these characteristics of sin stocks (low beta, high HML loading, and significantly negative beta on the long-short portfolio) should not vary throughout the different specifications of the model testing.

Next, I examine which cultural and legal environment is more favorable for sin stock returns and how it determines the expected returns on these stocks. The first hypothesis I test is whether there is a risk premium on sin stocks in Protestant countries. Table 8 shows the empirical results for both Catholic and Protestant countries. In Catholic countries, there is no abnormal return on any of the portfolios, which is consistent with my prediction that Catholics do not exhibit any "sin aversion". In Protestant countries, the average risk-adjusted return on sin stocks is significantly positive, but the statistical significance disappears after controlling for the size and value effects. However, the abnormal performance of the long-short portfolio is still significant with the three-factor model, and equals $5.7 \%$ on an annual basis. This result is consistent with my "sin aversion" hypothesis. It seems that Protestant investors require a considerable premium on sin stocks, whereas Catholics price these stocks without any premium.

My second hypothesis is whether a higher litigation risk implies higher risk-adjusted returns on sin stocks. Estimates for both number of lawyers and litigation rate are reported in Table 9. Although 
the countries are not the same ones in both groupings, coefficient estimates are really close. Sin stocks have higher risk-adjusted returns when the litigation risk is higher, but this difference vanishes when controlling for size and book-to-market. On the other hand, non-sin stocks exhibit lower risk-adjusted returns in the presence of elevated litigation risk. If the difference between low and high litigation risk is not statistically significant, the economic magnitude is important. However, the long-short portfolio has a significant alpha for countries with high litigation risk: 5.5\% annually for the variable Number of lawyers, and $5.8 \%$ for the variable Litigation rate.

The last hypothesis I want to test is whether higher excise taxation implies higher risk-adjusted returns on sin stocks, but not on other stocks. I know that my groups of countries based on beer excise taxation are close to those based on religion; but I concentrate here on the difference between sin stock returns when excise tax is high and sin stock returns when tax is low. The coefficient estimates are given in Table 10. The abnormal return on the long-short portfolio, for both CAPM and three-factor model, is significant at the five percent level for countries with high excise taxation, which is consistent with my previous result on religion. If I look carefully at my sin portfolios, I see that there is a huge difference in the risk-adjusted return between the low excise group and the high excise group. Indeed, this difference is statistically significant at a five percent level (t-statistic equals 1.89 for the three-factor model). This result is consistent with the idea that both religion and excise taxation could help explain the variation of sin stock returns.

\section{v. Conclusion}

Previous literature finds that sin stocks (publicly-traded companies involved in producing tobacco, alcohol, and gambling) behave differently than other stocks, in the sense that they earn abnormal returns because of negligence. I investigate other possible determinants of their risk-adjusted expected returns, related to differences in legal and cultural environment. Using a sample of 18 European countries, I provide evidence that sin stock performance depends on both the legislation and the religious environment. Over the period 1975-2006, my results show that sin stocks outperform other stocks in Protestant countries, because of "sin aversion", and in countries with higher litigation risk, because of a high level of external costs. Another interesting result is that sin stock returns vary 
with the level of excise taxation on alcohol and tobacco products. Sin stocks earn significantly higher abnormal returns in countries where the excise taxation is high. Although my data does not allow gauging the relative importance of these effects, evidence is given that the predictability of average sin stock returns depends on country-specific factors such as religion, litigation risk, and excise taxation.

Further investigation could be to look at sin stock returns in countries with other religious denominations, such as Muslims countries; but the problem of sample size in terms of number of publicly-traded sin stocks could perhaps be even more important. As robustness checks, it would also be interesting to find time-varying measures for litigation risk and excise taxation, in order to study the impact of time-series variation in these measures on the variation in sin stock returns. In addition, this study does not answer the issue of segmented vs. integrated markets. The underlying assumption of my paper is that European markets are segmented, what can be subject to debate. However, the main objective of this paper is to help explain both time-series and cross-sectional returns, as well as investors' behaviour, in international markets. 
Table 1: Characteristics of the data, per country

Part $A$ indicates the number of firms for each country in the entire database in December 1985, 1995 and 2005. Part B shows the average size (market capitalization, price times shares outstanding) of firms of each country, per year. Part $C$ shows the median firm size per country and per year. Average size and median size are in millions of euro. Part $D$ indicates the average price-to-book value ratio (the share price divided by the book value per share) for each country and each year 1985, 1995 and 2005. The 18 countries are Austria (AU), Belgium (BE), the Czech Republic (CZ), Denmark (DK), Finland (FI), France (FR), Germany (GM), Greece (GR), Hungary (HU), Ireland (IR), Italy (IT), the Netherlands (NL), Poland (PL), Portugal (PR), Spain (SP), Sweden (SW), Switzerland (SZ), and the United-Kingdom (UK).

\begin{tabular}{|c|r|r|r|r|r|r|r|r|r|r|r|r|}
\cline { 2 - 12 } \multicolumn{1}{c|}{} & \multicolumn{2}{c|}{ A. Number of firms } & \multicolumn{3}{c|}{ B. Average size } & \multicolumn{3}{c|}{ C. Median size } & \multicolumn{2}{c|}{ D. Average P/B } \\
\hline Country & \multicolumn{1}{c|}{1985} & 1995 & 2005 & \multicolumn{1}{c|}{1985} & 1995 & 2005 & 1985 & 1995 & 2005 & 1985 & 1995 & 2005 \\
\hline AU & 15 & 47 & 59 & 41 & 234 & 812 & 19 & 70 & 102 & 1.23 & 1.98 & 2.60 \\
BE & 19 & 47 & 100 & 194 & 424 & 1044 & 64 & 64 & 129 & 0.91 & 1.47 & 2.09 \\
CZ & & 51 & 24 & & 76 & 888 & & 28 & 158 & & 0.98 & 1.73 \\
DK & 14 & 53 & 71 & 145 & 222 & 815 & 111 & 61 & 109 & 1.32 & 1.70 & 6.75 \\
FI & & 50 & 111 & & 390 & 1116 & & 90 & 130 & & 1.24 & 2.15 \\
FR & 60 & 296 & 681 & 546 & 777 & 1560 & 273 & 80 & 50 & 1.78 & 1.69 & 4.86 \\
GM & 88 & 287 & 725 & 853 & 661 & 940 & 255 & 78 & 32 & 2.12 & 2.87 & 2.46 \\
GR & & 133 & 262 & & 46 & 227 & & 21 & 28 & & 2.33 & 1.18 \\
HU & & 16 & 30 & & 44 & 603 & & 13 & 45 & & 0.91 & 1.07 \\
IR & 15 & 27 & 46 & 45 & 225 & 994 & 16 & 70 & 271 & 1.04 & 1.51 & 2.73 \\
IT & 23 & 73 & 195 & 286 & 484 & 1819 & 77 & 123 & 214 & 1.49 & 1.51 & 1.91 \\
NL & 53 & 85 & 113 & 876 & 1589 & 2785 & 67 & 135 & 287 & 1.55 & 2.67 & 3.02 \\
PL & & 13 & 208 & & 58 & 160 & & 14 & 24 & & 0.98 & 1.93 \\
PR & & 51 & 50 & & 113 & 729 & & 13 & 89 & & 1.08 & 1.75 \\
SP & & 58 & 92 & & 912 & 3245 & & 159 & 577 & & 37.93 & 3.37 \\
SW & 15 & 82 & 313 & 149 & 285 & 456 & 98 & 51 & 42 & 1.98 & 1.81 & 3.25 \\
SZ & 41 & 99 & 157 & 114 & 307 & 570 & 74 & 93 & 186 & 2.67 & 1.57 & 2.43 \\
UK & 404 & 631 & 1480 & 424 & 911 & 1151 & 26 & 75 & 55 & 2.15 & 3.37 & 5.01 \\
\hline
\end{tabular}


Table 2: Characteristics of the sin stocks

Table 2 compares sin stocks to other stocks, over the period 1980-2006. Part A indicates the number of sin stocks in December of each year. Part B shows the average size (market capitalization, price times shares outstanding) of stocks for each year. Part $C$ shows the median firm size for the sin sample and the non-sin sample. Average size and median size are in millions of euro and. Part D indicates the average ratio price-to-book value (the share price divided by the book value per share) for sin stocks and other stocks for each year.

\begin{tabular}{|c|c|c|c|c|c|c|c|c|}
\hline \multirow[b]{2}{*}{ Year } & \multicolumn{2}{|c|}{ A. Number of firms } & \multicolumn{2}{|c|}{ B. Average size } & \multicolumn{2}{|c|}{ C. Median size } & \multicolumn{2}{|c|}{ D. Average P/B } \\
\hline & non-sin & $\sin$ & non-sin & $\sin$ & non-sin & $\sin$ & non-sin & $\sin$ \\
\hline 1980 & 578 & 20 & 206 & 198 & 22 & 73 & 1.09 & 0.69 \\
\hline 1981 & 600 & 23 & 219 & 220 & 24 & 67 & 1.10 & 0.66 \\
\hline 1982 & 616 & 22 & 227 & 297 & 26 & 72 & 0.97 & 0.77 \\
\hline 1983 & 647 & 23 & 296 & 423 & 34 & 89 & 1.31 & 1.16 \\
\hline 1984 & 693 & 23 & 342 & 554 & 44 & 86 & 1.57 & 1.37 \\
\hline 1985 & 750 & 23 & 447 & 719 & 56 & 115 & 1.96 & 1.56 \\
\hline 1986 & 838 & 27 & 517 & 878 & 66 & 140 & 2.43 & 2.20 \\
\hline 1987 & 914 & 28 & 582 & 1004 & 76 & 146 & 5.26 & 2.18 \\
\hline 1988 & 1217 & 55 & 490 & 760 & 63 & 62 & 4.44 & 2.01 \\
\hline 1989 & 1407 & 56 & 532 & 762 & 69 & 49 & 4.02 & 2.93 \\
\hline 1990 & 1455 & 56 & 514 & 749 & 62 & 67 & 3.69 & 3.05 \\
\hline 1991 & 1552 & 57 & 533 & 854 & 58 & 63 & 5.26 & 3.13 \\
\hline 1992 & 1592 & 59 & 539 & 982 & 53 & 66 & 6.02 & 2.70 \\
\hline 1993 & 1723 & 62 & 607 & 965 & 58 & 66 & 8.65 & 2.43 \\
\hline 1994 & 1885 & 66 & 671 & 947 & 71 & 67 & 10.36 & 2.43 \\
\hline 1995 & 2075 & 72 & 634 & 874 & 68 & 53 & 14.53 & 2.31 \\
\hline 1996 & 2347 & 75 & 740 & 889 & 74 & 52 & 16.23 & 2.71 \\
\hline 1997 & 2669 & 79 & 946 & 1059 & 87 & 69 & 41.00 & 2.72 \\
\hline 1998 & 3051 & 83 & 1083 & 1453 & 87 & 109 & 3.80 & 8.47 \\
\hline 1999 & 3590 & 92 & 1255 & 1384 & 89 & 134 & 4.24 & 3.99 \\
\hline 2000 & 4140 & 99 & 1555 & 1340 & 106 & 129 & 1.04 & 3.46 \\
\hline 2001 & 4353 & 105 & 1196 & 1519 & 66 & 106 & 3.17 & 2.70 \\
\hline 2002 & 4374 & 104 & 951 & 1667 & 47 & 99 & 1.91 & 2.67 \\
\hline 2003 & 4430 & 106 & 818 & 1451 & 42 & 112 & 2.20 & 4.74 \\
\hline 2004 & 4539 & 111 & 947 & 1729 & 53 & 139 & 2.97 & 4.36 \\
\hline 2005 & 4747 & 123 & 1075 & 1985 & 59 & 145 & 3.59 & 4.89 \\
\hline 2006 & 4434 & 108 & 1280 & 2339 & 73 & 163 & 5.94 & 6.18 \\
\hline
\end{tabular}


Table 3: Primary religion in each European country

This Table shows the proportion of each country population affiliated in a major religion. The primary religion is defined as the one practiced by the largest fraction of the population of a country.

\begin{tabular}{|c|c|c|c|c|}
\hline Country & $\begin{array}{l}\text { Primary } \\
\text { Religion }\end{array}$ & $\begin{array}{l}\text { Percent } \\
\text { Catholic }\end{array}$ & $\begin{array}{c}\text { Percent } \\
\text { Protestant }\end{array}$ & $\begin{array}{c}\text { Percent } \\
\text { Greek } \\
\text { Orthodox }\end{array}$ \\
\hline Austria & Catholic & 85 & 6 & - \\
\hline Belgium & Catholic & 75 & - & - \\
\hline Czech Republic & Catholic & 39 & 5 & - \\
\hline Denmark & Protestant & - & 95 & - \\
\hline Finland & Protestant & - & 90 & - \\
\hline France & Catholic & 81 & 2 & - \\
\hline Germany & Protestant & 34 & 38 & - \\
\hline Greece & Orthodox & - & - & 98 \\
\hline Hungary & Catholic & 67 & 25 & - \\
\hline Ireland & Catholic & 93 & 3 & - \\
\hline Italy & Catholic & 98 & - & - \\
\hline Netherlands & Catholic & 34 & 25 & - \\
\hline Poland & Catholic & 95 & - & - \\
\hline Portugal & Catholic & 97 & 1 & - \\
\hline Spain & Catholic & 98 & - & - \\
\hline Sweden & Protestant & 2 & 94 & - \\
\hline Switzerland & Catholic & 49 & 40 & - \\
\hline UK & Protestant & 16 & 43 & - \\
\hline
\end{tabular}


Table 4: Classification of countries according to religious denomination, church attendance, and religious beliefs

This Table contains all countries classified according to their primary religion vs. the degree of church attendance (Panel A), and according to the level of religious beliefs vs. the degree of church attendance (Panel B). Primary religion is from Stulz and Williamson (2003), data on church attendance and religious beliefs is from various sources, including McCleary and Barro (2006) and Guiso, Sapienza, and Zingales (2003).

PANEL A: Religious preference vs. church attendance

\begin{tabular}{|l|l|l|}
\cline { 2 - 3 } \multicolumn{1}{c|}{} & \multicolumn{1}{|c|}{ Low Attendance } & \multicolumn{1}{c|}{ High Attendance } \\
\hline Catholic & Czech Rep., France, Hungary & $\begin{array}{l}\text { Austria, Belgium, Ireland, Italy, } \\
\text { Netherlands, Poland, Portugal, Spain }\end{array}$ \\
\hline Protestant & $\begin{array}{l}\text { Denmark, Finland, Germany, Sweden, } \\
\text { UK }\end{array}$ & \\
\hline
\end{tabular}

PANEL B: Religious beliefs vs. church attendance

\begin{tabular}{|l|l|l|}
\cline { 2 - 3 } \multicolumn{1}{c|}{} & \multicolumn{1}{c|}{ Low Attendance } & \multicolumn{1}{c|}{ High Attendance } \\
\hline Low Religious Beliefs & $\begin{array}{l}\text { Czech Rep., Denmark, France, } \\
\text { Germany, Hungary, Sweden, UK }\end{array}$ & Belgium, Netherlands \\
\hline High Religious Beliefs & Finland, Greece & $\begin{array}{l}\text { Austria, Ireland, Italy, Poland, } \\
\text { Portugal, Spain }\end{array}$ \\
\hline
\end{tabular}


Table 5: Rule of law and litigation measures, per country

This Table contains, for each country, a measure for the tradition of law - rule of law - and two measures of litigation risk - number of lawyers and litigation rate. Countries are ranked by increasing rule of law. Data on the rule of law is from the World Bank, and represents a relative index of enforcement in each country - the higher rule of law being 100. The number of lawyers per country is from the 2006 CEPEJ Report on European judicial systems, and data on litigation rate is from Wollschlager (1998). The number of lawyers is given per 100,000 inhabitants, whereas the litigation rate represents the number of cases per 1,000 inhabitants.

\begin{tabular}{|l|c|c|c|}
\hline \multicolumn{1}{|c|}{ Country } & Rule of Law & $\begin{array}{c}\text { Number of } \\
\text { Lawyers }\end{array}$ & $\begin{array}{c}\text { Litigation } \\
\text { Rate }\end{array}$ \\
\hline Poland & 59.9 & 14.4 & 23 \\
Italy & 64.3 & 259.1 & \\
Greece & 68.1 & 307.5 & 20 \\
Hungary & 69.6 & 94.1 & 52 \\
Czech Republic & 70.0 & 80.6 & 22 \\
Portugal & 84.5 & 212.9 & 41 \\
Spain & 85.0 & 259.3 & 16 \\
France & 89.9 & 70.7 & 40 \\
Belgium & 90.8 & 142.4 & \\
Ireland & 92.3 & 229.5 & 32 \\
UK & 93.2 & 200.7 & 64 \\
Germany & 93.7 & 153.7 & 123 \\
Netherlands & 94.2 & 80.5 & 16 \\
Sweden & 96.1 & 48.2 & 111 \\
Austria & 96.6 & 34.0 & 96 \\
Finland & 97.6 & 32.5 & \\
Denmark & 98.6 & 85.9 & 62 \\
\hline
\end{tabular}


Table 6: Excise duty rates on tobacco and alcoholic beverages, per country (in euro)

This Table contains excise duty rates on tobacco and alcohol products. Countries are ranked by increasing excise tax on beer. The excise tax on tobacco is given in euro, per pack of 20 cigarettes, and figures are for 2003. The excise duty rates on alcoholic drinks are also given in euro, and data is for 2006. Beer excise tax is based on $5 \%$ abv (alcohol by volume), wine excise duty is based on $12 \%$ abv, and spirits tax is given for $40 \%$ abv.

\begin{tabular}{|l|c|c|c|c|}
\hline \multicolumn{1}{|c|}{ Country } & Tobacco & Beer (per 0.5 litre) & Wine (per 75cl) & Spirits (per 70cl) \\
\hline Czech Republic & 0.53 & 0.04 & 0.00 & 2.51 \\
Germany & 2.05 & 0.04 & 0.00 & 3.65 \\
Spain & 1.13 & 0.05 & 0.00 & 2.32 \\
Greece & 1.35 & 0.06 & 0.00 & 3.05 \\
Portugal & 1.30 & 0.08 & 0.00 & 2.62 \\
Belgium & 1.67 & 0.09 & 0.35 & 4.91 \\
Poland & 0.50 & 0.09 & 0.26 & 3.25 \\
Austria & 1.56 & 0.10 & 0.00 & 2.80 \\
Hungary & & 0.10 & 0.00 & 2.46 \\
Italy & 1.20 & 0.12 & 0.00 & 2.24 \\
France & 2.30 & 0.13 & 0.03 & 4.06 \\
Netherlands & 1.65 & 0.13 & 0.44 & 4.21 \\
Denmark & 2.49 & 0.34 & 0.62 & 5.63 \\
Sweden & 2.05 & 0.79 & 1.78 & 15.08 \\
UK & 4.67 & 0.95 & 1.90 & 8.05 \\
Finland & 2.30 & 0.97 & 1.59 & 7.91 \\
Ireland & 3.42 & 0.99 & 2.05 & 10.99 \\
\hline
\end{tabular}




\section{Table 7: Empirical Results of one-factor and three-factor regressions, for all countries}

This Table contains the estimator coefficients described in Equations (1) and (2) for the sin stock and the non-sin stock portfolio returns in excess of the risk-free rate, and for the zero-investment portfolio, long on sin stocks and short on other stocks. Equation (1) is estimated over the period January 1975December 2006. Equation (2) is estimated over the period July 1981-December 2006. R-squares are percentages. Standard errors are in parentheses.

${ }^{* * *}$ indicates significance at the 1 percent level.

** indicates significance at the 5 percent level.

* indicates significance at the 10 percent level.

\begin{tabular}{lccccc} 
& Intercept & ExRm & SMB & HML & R-sq \\
\cline { 2 - 6 } Sin - Rf & $0.0033^{\star}$ & $0.7651^{\star \star \star}$ & & & 50.39 \\
& $(0.0018)$ & $(0.0388)$ & & & \\
& 0.0030 & $0.7243^{\star \star *}$ & $-0.1446^{\star}$ & $0.2684^{\star \star \star}$ & 50.35 \\
& $(0.0021)$ & $(0.0442)$ & $(0.0744)$ & $(0.0731)$ & \\
NoSin - Rf & $-0.0010^{\star \star *}$ & $0.9993^{\star \star *}$ & & & 99.79 \\
& $(0.0001)$ & $(0.0023)$ & & & \\
& $-0.0011^{\star \star *}$ & $1.0086^{\star \star *}$ & 0.0042 & -0.0001 & 99.86 \\
& $(0.0001)$ & $(0.0022)$ & $(0.0037)$ & $(0.0036)$ & \\
Sin - NoSin & $0.0044^{\star \star}$ & $-0.2343^{\star \star *}$ & & & \\
& $(0.0019)$ & $(0.0405)$ & & & 08.05 \\
& $0.0041^{*}$ & $-0.2843^{\star \star *}$ & $-0.1488^{*}$ & $0.2684^{\star \star *}$ & 15.63 \\
& $(0.0022)$ & $(0.0461)$ & $(0.0775)$ & $(0.0761)$ &
\end{tabular}


Table 8: Empirical Results of one-factor and three-factor regressions, for Catholic and Protestant countries

This Table contains the estimator coefficients described in Equations (1) and (2) for the sin stock and the non-sin stock portfolio returns in excess of the riskfree rate, and for the zero-investment portfolio, long on sin stocks and short on other stocks. Equation (1) is estimated over the period January 1975December 2006. Equation (2) is estimated over the period July 1981-December 2006. R-squares are percentages. Standard errors are in parentheses.

*** indicates significance at the 1 percent level.

** indicates significance at the 5 percent level.

* indicates significance at the 10 percent level.

\begin{tabular}{|c|c|c|c|c|c|c|c|c|c|c|c|c|c|c|}
\hline & Catholic & ountries & & & & Protestant & Countries & & & & t-stat (diff & rence) & & \\
\hline & Intercept & ExRm & SMB & $\mathrm{HML}$ & R-sq & Intercept & ExRm & SMB & $\mathrm{HML}$ & R-sq & Intercept & ExRm & SMB & $\mathrm{HML}$ \\
\hline Sin - Rf & 0.0027 & $0.6170^{\star \star \star}$ & & & 29.61 & $0.0039^{\star}$ & $0.8064^{\star \star \star}$ & & & 43.60 & -0.47 & -16.46 & & \\
\hline & $(0.0022)$ & $(0.0487)$ & & & & $(0.0021)$ & $(0.0469)$ & & & & & & & \\
\hline & 0.0033 & $0.6449^{\star \star \star}$ & 0.1396 & $0.2713^{\star * *}$ & 34.50 & 0.0033 & $0.7351^{\star \star \star}$ & $-0.2530^{\star \star \star}$ & $0.2818^{\star * \star}$ & 43.84 & 0.02 & -6.74 & 22.20 & -0.60 \\
\hline & $(0.0025)$ & $(0.0521)$ & $(0.0877)$ & $(0.0862)$ & & $(0.0025)$ & $(0.0528)$ & (0.0888) & $(0.0872)$ & & & & & \\
\hline NoSin - Rf & 0.00002 & $0.95667^{\star \star \star}$ & & & 83.37 & $-0.0016^{\star \star \star}$ & $1.0199^{\star \star \star}$ & & & 95.56 & 1.02 & -8.35 & & \\
\hline & $(0.0010)$ & $(0.0219)$ & & & & $(0.0005)$ & $(0.0112)$ & & & & & & & \\
\hline & -0.0004 & $0.9964^{\star \star \star}$ & $0.0987^{\star \star \star}$ & $0.0701^{*}$ & 87.33 & $-0.0013^{\star \star}$ & $1.0103^{\star \star \star}$ & $-0.0671^{\star * *}$ & $-0.0387^{\star}$ & 96.20 & 0.50 & -1.63 & 14.96 & 9.92 \\
\hline & $(0.0010)$ & $(0.0221)$ & $(0.0371)$ & $(0.0365)$ & & $(0.0006)$ & $(0.0119)$ & $(0.0201)$ & $(0.0197)$ & & & & & \\
\hline Sin - NoSin & 0.0027 & $-0.3397^{\star * \star}$ & & & 12.01 & $0.0055^{\star \star \star}$ & $-0.2135^{\star \star \star}$ & & & 05.57 & -1.17 & -11.17 & & \\
\hline & $(0.0022)$ & $(0.0470)$ & & & & $(0.0021)$ & $(0.0454)$ & & & & & & & \\
\hline & 0.0037 & $-0.3515^{\star \star \star}$ & 0.0409 & $0.2012^{\star \star}$ & 16.08 & $0.0046^{\star}$ & $-0.2752^{\star \star \star}$ & $-0.1859^{\star \star}$ & $0.3206^{\star \star \star}$ & 13.89 & -0.31 & -5.75 & 12.95 & -6.88 \\
\hline & $(0.0024)$ & $(0.0513)$ & $(0.0863)$ & $(0.0847)$ & & $(0.0025)$ & $(0.0517)$ & $(0.0870)$ & $(0.0855)$ & & & & & \\
\hline
\end{tabular}


Table 9: Empirical Results of one-factor and three-factor regressions, for two groups of countries based on the degree of litigation risk

This Table contains the estimator coefficients described in Equations (1) and (2) for the sin stock and the non-sin stock portfolio returns in excess of the riskfree rate, and for the zero-investment portfolio, long on sin stocks and short on other stocks. Equation (1) is estimated over the period January 1975December 2006. Equation (2) is estimated over the period July 1981-December 2006. R-squares are percentages. Standard errors are in parentheses.

*** indicates significance at the 1 percent level.

** indicates significance at the 5 percent level.

* indicates significance at the 10 percent level.

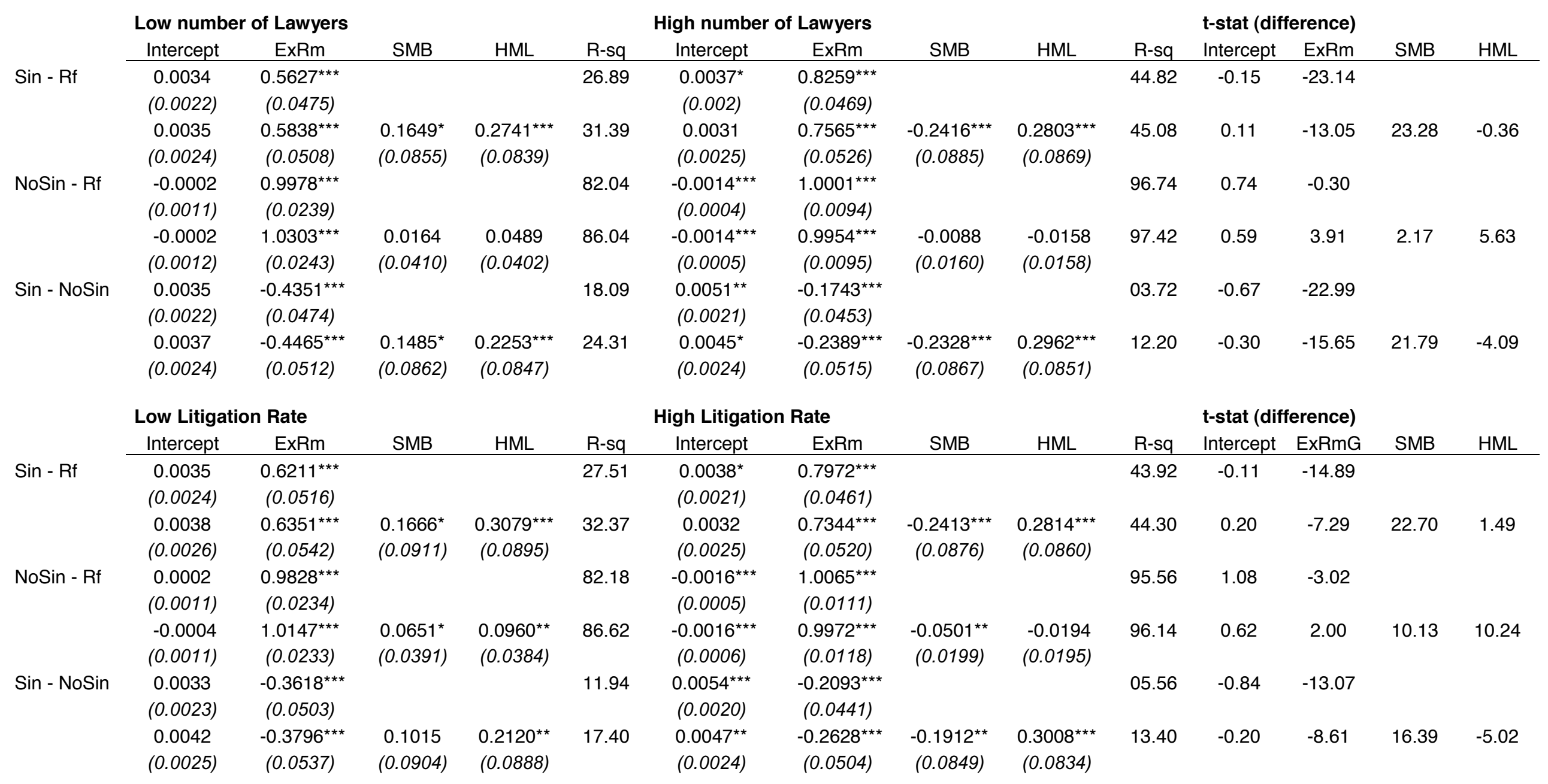




\section{Table 10: Empirical Results of one-factor and three-factor regressions, for two groups of countries based on their level of excise taxation}

This Table contains the estimator coefficients described in Equations (1) and (2) for the sin stock and the non-sin stock portfolio returns in excess of the riskfree rate, and for the zero-investment portfolio, long on sin stocks and short on other stocks. Equation (1) is estimated over the period January 1975December 2006. Equation (2) is estimated over the period July 1981-December 2006. R-squares are percentages. Standard errors are in parentheses.

*** indicates significance at the 1 percent level.

** indicates significance at the 5 percent level.

* indicates significance at the 10 percent level.

\begin{tabular}{|c|c|c|c|c|c|c|c|c|c|c|c|c|c|c|}
\hline & \multicolumn{4}{|c|}{ Low Excise Tax on Beer } & \multicolumn{6}{|c|}{ High Excise Tax on Beer } & \multicolumn{4}{|c|}{ t-stat (difference) } \\
\hline & Intercept & ExRm & SMB & HML & $\mathrm{R}$-sq & Intercept & ExRm & SMB & $\mathrm{HML}$ & $\mathrm{R}$-sq & Intercept & ExRm & SMB & $\mathrm{HML}$ \\
\hline \multirow[t]{4}{*}{$\operatorname{Sin}-\mathrm{Rf}$} & -0.0021 & $0.4706^{\star \star \star}$ & & & 18.03 & $0.0042^{\star \star}$ & $0.8387^{\star \star \star}$ & & & 48.91 & -2.53 & -31.26 & & \\
\hline & $(0.0023)$ & $(0.0513)$ & & & & $(0.0020)$ & $(0.0439)$ & & & & & & & \\
\hline & -0.0021 & $0.5708^{\star \star \star}$ & $0.1614^{\star}$ & $0.2720^{\star}$ & 25.09 & 0.0036 & $0.7347^{\star \star \star}$ & $-0.1727^{\star \star}$ & $0.2658^{\star \star \star}$ & 47.81 & -1.89 & -11.67 & 18.11 & 0.34 \\
\hline & $(0.0028)$ & $(0.0581)$ & $(0.0977)$ & $(0.0960)$ & & $(0.0023)$ & $(0.0475)$ & $(0.0799)$ & $(0.0785)$ & & & & & \\
\hline \multirow[t]{4}{*}{ NoSin - Rf } & $-0.0029^{\star \star}$ & $0.8702^{\star \star \star}$ & & & 68.19 & -0.0001 & $1.0873^{\star \star \star}$ & & & 94.56 & -1.50 & -24.32 & & \\
\hline & $(0.0014)$ & $(0.0304)$ & & & & $(0.0006)$ & (0.0133) & & & & & & & \\
\hline & -0.0013 & $0.9457^{\star \star \star}$ & $0.0942^{*}$ & $-0.1300^{\star *}$ & 73.28 & $-0.0009^{\star}$ & $1.0364^{\star \star \star}$ & $-0.0371^{* *}$ & $0.0406^{\star *}$ & 96.83 & -0.17 & -8.64 & 9.64 & -12.64 \\
\hline & $(0.0016)$ & $(0.0335)$ & $(0.0564)$ & $(0.0554)$ & & $(0.0005)$ & $(0.0111)$ & $(0.0186)$ & (0.0183) & & & & & \\
\hline \multirow[t]{4}{*}{ Sin - NoSin } & 0.0008 & $-0.3997^{\star \star *}$ & & & 13.75 & $0.0042^{\star *}$ & $-0.2486^{\star \star \star}$ & & & 08.09 & -1.38 & -12.85 & & \\
\hline & $(0.0023)$ & $(0.0512)$ & & & & $(0.0020)$ & $(0.0429)$ & & & & & & & \\
\hline & -0.0008 & $-0.3749^{\star \star \star}$ & 0.0672 & $0.4020^{\star * \star}$ & 17.37 & $0.0045^{\star \star}$ & $-0.3017^{\star \star \star}$ & $-0.1356^{\star}$ & $0.2251^{\star \star \star}$ & 14.82 & -1.75 & -5.17 & 10.90 & 9.59 \\
\hline & (0.0028) & (0.0592) & $(0.0996)$ & $(0.0978)$ & & $(0.0023)$ & $(0.0475)$ & $(0.0800)$ & $(0.0786)$ & & & & & \\
\hline
\end{tabular}


Figure 1: Plot of Number of lawyers vs. Litigation rate

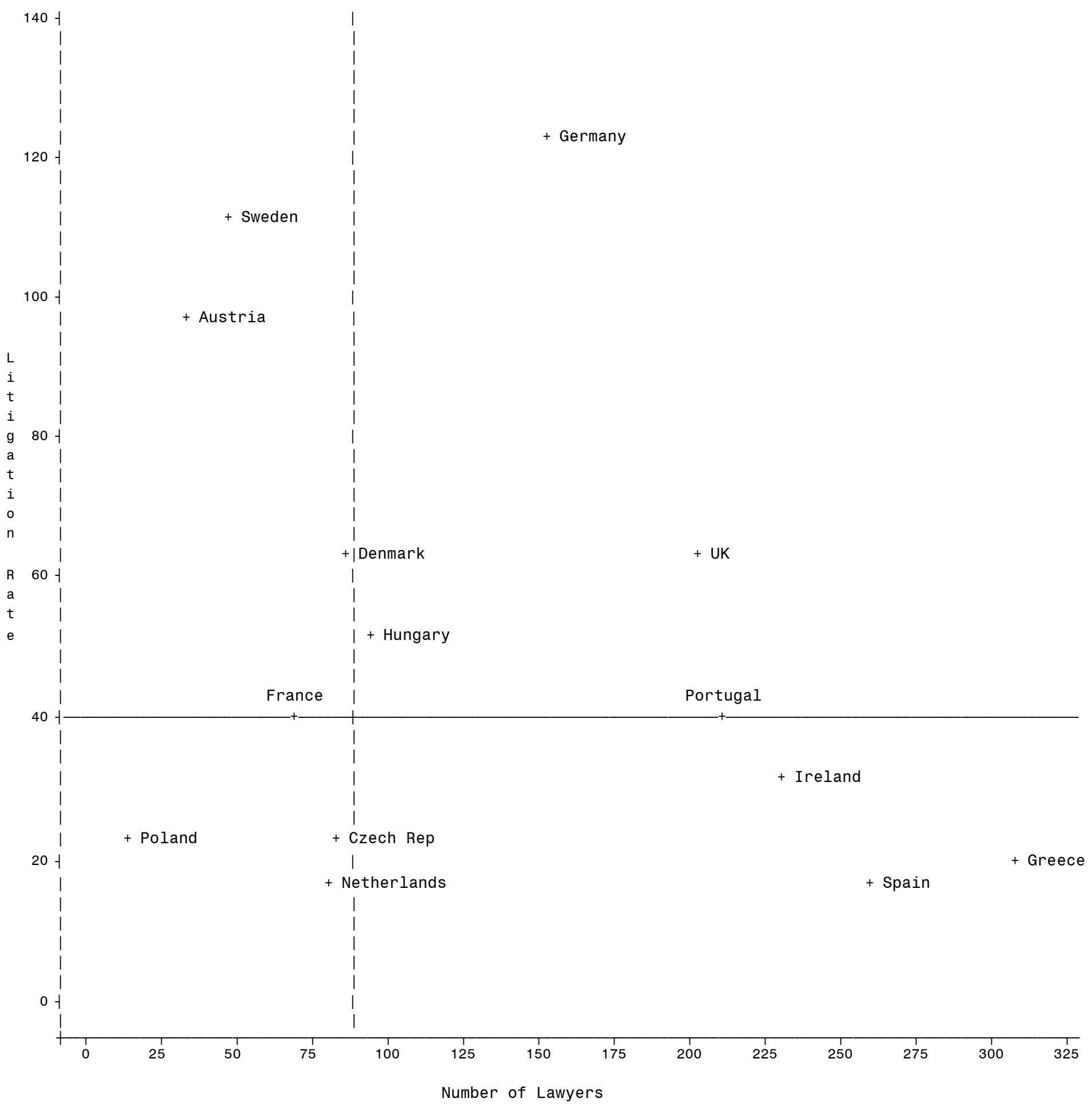


Figure 2: Plot of Tobacco excise tax vs. Beer excise tax

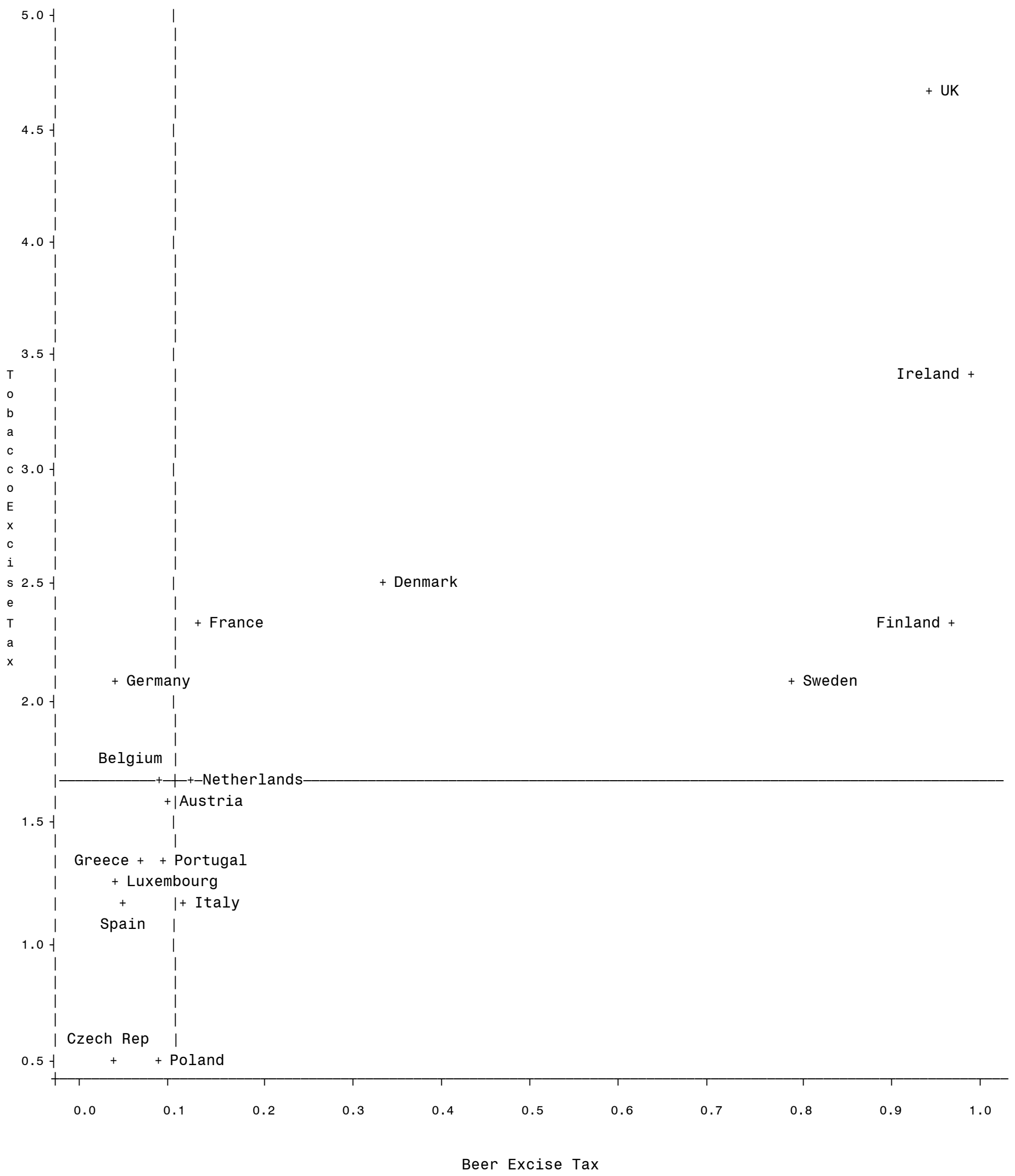




\section{References}

Ahrens, Dan. 2004. Investing in Vice, New York: St. Martin's Press.

Babor, T.F., R. Caetano, S. Casswell, G. Edwards, N. Giesbrecht, K. Graham, J. Grube, P. Gruenewald, L. Hill, H. Holder, R. Homel, E. Österberg, E.J. Rehm, and I. Rossow. 2003. Alcohol: No Ordinary Commodity - Research and Public Policy. Oxford University Press, Oxford.

Cnossen, S. 2005. Theory and Practice of Excise Taxation: Smoking, Drinking, Gambling, Polluting, and Driving, S. Cnossen (ed.), Oxford: Oxford University Press.

Cnossen, Sijbren. 2006. Alcohol Taxation and Regulation in the European Union: SSRN.

Corlett, W. J., and D. C. Hague. 1953. Complementarity and the Excess Burden of Taxation. The Review of Economic Studies 21 (1):21-30.

Fairbanks, David. 1977. Religious Forces and "Morality" Policies in the American States. The Western Political Quarterly 30 (3):411-417.

Fama, Eugene F., and Kenneth R. French. 1993. Common Risk Factors in the Returns on Stocks and Bonds. Journal of Financial Economics 33, 3-56.

Fama, Eugene F., and Kenneth R. French. 1998. Value versus Growth: The International Evidence. Journal of Finance 53, 6, 1975-1999.

Guiso, Luigi, Paola Sapienza, and Luigi Zingales. 2003. People's opium? Religion and economic attitudes. Journal of Monetary Economics 50 (1):225-282.

Harvey, Campbell R. 1991. The World Price of Covariance Risk. Journal of Finance 46, 111-155.

Hilary, Gilles, and Kai Wai Hui. 2006. The Influence of Corporate Culture on Economic Behavior: Does Religion Matter in Corporate Decision Making in America? Working Paper, HKUST.

Hong, Harrison, and Marcin Kacperczyk. 2007. The Price of Sin: The Effects of Social Norms on Markets. Working Paper.

Hutcheson, John D., Jr., and George A. Taylor. 1973. Religious Variables, Political System Characteristics, and Policy Outputs in the American States. American Journal of Political Science 17 (2):414-421.

Iannaccone, Laurence R. 1998. Introduction to the economics of religion. Journal of Economic Literature 36 (3):1465.

Ince, Ozgur S., and R. Burt Porter. 2006. Individual Equity Return Data from Thomson DataStream: Handle with Care! Journal of Financial Research 29, 4, 463-479.

Jacob, Jeffry, and Thomas Osang. 2006. Values, Beliefs, and Development. Working Paper, Southern Methodist University.

Johnson, Cathy M., and Kenneth J. Meier. 1990. The Wages of Sin: Taxing America's Legal Vices. The Western Political Quarterly 43 (3):577-595. 
Kim, Irene, and Mohan Venkatachalam. 2006. Are sin stocks paying the price for their accounting sins? Working Paper, Duke University.

La Porta, Rafael, Florencio Lopez-de-Silanes, Andrei Shleifer, and Robert W. Vishny. 1997. Legal Determinants of External Finance. Journal of Finance 52, 3, 1131-1150.

Lintner, John. 1965. The Valuation of Risk Assets and the Selection of Risky Investments in Stock Portfolios and Capital Budgets. Review of Economics and Statistics 47, 13-37.

McCleary, Rachel M., and Robert J. Barro. 2006. Religion and Political Economy in an International Panel. Journal for the Scientific Study of Religion 45 (2):149-175.

Ramsey, F. 1927. A Contribution to the Theory of Taxation, Economic Journal, 47-61.

Sharpe, William F. 1964. Capital Asset Prices: A Theory of Market Equilibrium under Conditions of Risk. Journal of Finance 19, 3, 425-442.

Stulz, Rene M., and Rohan Williamson. 2003. Culture, openness, and finance. Journal of Financial Economics 70 (3):313-349.

Van Liemt, G. 2002. The world tobacco industry: Trends and prospects. Geneva, International Labour Office, Working Paper 179.

Waxler, Caroline. 2004. Stocking Up On Sin: How to Crush the Market with Vice-Based Investing, Published by Hoboken, NJ: Wiley.

Wollschlager, C. 1998. Exploring global landscapes of litigation rates. In: Brand J, Strempel D (eds.) Soziologie des Rechts: Festschrift für Erhard Blankenburg zum 60. Geburtstag. Nomos, Baden-Baden, Germany. 